\title{
A Study on Establishing Competency Profile Standard of Teacher Librarian in Optimizing the Use of ICT in Secondary Level School Library
}

\author{
Yooke Tjuparmah \\ yooke_tj@yahoo.co.id \\ Riche Cynthia Johan \\ riche@upi.edu \\ R. Nadia Hanoum \\ nadia.hanum@gmail.com \\ Library and Information Study Program \\ Indonesia University of Education
}

\begin{abstract}
Teacher librarians are expected to have good skills in using information and communication technology (ICT) so that they can assist both students and teachers in finding the information they need. The aim of this study was to establish the competency profile standard of teacher librarians using ICT at the secondary level. More specifically, this study would like to find out the competency profile of teacher librarians, the optimization of the use of ICT by teacher librarians, and the competency standard required in using ICT for teacher librarians in secondary level. This study used qualitative approach with survey method and the data was collected through interview and observation. The general conclusion is that the library administrators/teacher librarians in the schools presented in this research always met and enhanced the competencies that supported their daily tasks in the library and in their field of study by trying to take advantage of hardware utilization to improve the library service to the users. Specifically, this study shows that library administrators/teacher librarians are the subject teachers who receive additional tasks to manage the library; have a willingness to study and make innovations in the library; and try to have information, media and technology literacy skills, as well as the ability to enliven the life and career related to their fields. The competency standard of the majority of library administrators/teacher librarians in using ICT is considered good, they show good attitude, knowledges and skills but are often hampered by the lack of infrastructure, budget, and practice training to apply ICT in the school library. This research recommends that library administrators/teacher librarians should have functional status as librarians, not educative function as subject teachers.
\end{abstract}

Keywords: School library, teacher librarian competencies, ICT competency

\section{A. Introduction}

The development of the education sector continues to go hand in hand with the rapid pace of development and constantly changing times. These changes can be problematic and challenge the education sector to continue improving its quality. The embodiment of optimum quality education can be started with optimizing the use of learning resources in school to support learning activities. This is because the use of appropriate learning resources will be able to help students in understanding the subject matter.

The existence of learning resources in schools is an external condition that aims to provide a forum for students to find information. Learning resources are also expected to increase 
students' knowledge and insight pertaining to lessons delivered by teachers in the classroom. The presence of learning resources also creates a more compelling learning process so as to stimulate students' thinking power in the learning process.

One learning resource in schools is the school library. The school library is one of the most important parts of the overall school program, that along with other educational components helps determine the success of the education and teaching process. The school library is established to support the attainment of the school's goals, that is education and learning as outlined in the school curriculum. The school library organization is set up so that the goal of education can be achieved more efficiently and more effectively with collective action.

School libraries should be managed properly so as to attract students to want to visit and make use of it. In this regard, the role of librarian as the manager of the library is huge. Together with the principal, teachers are required to be able to create school libraries as a learning resources that is worth it to be utilized. Law 43 of 2007 about libraries has set a good standard for a library. This was done given the importance of the role of librarian in providing library service to library users.

To improve the service of libraries in facilitating students' and teachers' use, the application of ICT usage in the service activity is needed. Nowadays, the application of ICT has spread in almost all areas, and library is no exception. Library as an information management institution is one of the application fields of information technology which is growing rapidly. The development of information technology applications can be seen from the development of the type of library that is always associated with information technology, started from manual library, automated library, and digital or cyber library.

The development parameter of library types is measured from the application of information technology that is used instead of other measures such as building size, number of collections, and number of users. The need for information and communication technology is closely related to the role of library as a force in the preservation and dissemination of knowledge and culture that develop along with writing, printing, educating, and human need for information.

School librarians should be able to serve the needs of the users such as demand for faster access to information required both from inside and outside the library. By doing so it is expected that the librarians are adepts in the use of information and communication technology so that they can help students and teachers as library users in finding the required information.

Based on this background, the researchers were interested in conducting a research study on establishing a competency profile standard of teacher librarians in optimizing the use of ICT in secondary level school libraries.

\section{B. Literature Review}

\section{School library}

a. Basic Concept of School Library

School library is one of library types that is managed and utilized in schools or madrasas. Simply put, Suherman (2009, p. 20) argues that "The school library is a library in the school functions to serve students in meeting the information needs." In addition Rahayuningsih (2007, p. 6) also argues that "The school library is a library that serves students, teachers and staff of a particular school." In line with this, Carter V. Good in Bafadal (2009, p. 4) states that "The school library is an organized collection in a space so as to be able to be used by students and teachers."

Starting from these notions, it can be concluded that a school library is a collection of library materials systematically managed within a particular space so that it can help students, teachers, and staff in performing teaching and learning activities in school. 


\section{b. Objectives and Benefits of School Library}

Organizing a school library is not just to collect and store reference materials only, but is also expected to help students and teachers in performing the teaching and learning activities. Lasa (2007) asserts the objectives of the establishment of school library are to foster students and teachers' interest in reading writing, to introduce information technology, to familiarize independent information access, and to cultivate talents and interests.

Basically, the purpose of a school library is as a vehicle of information needed by students, teachers, and staff in the school so that the process of information dissemination in the school can run well. The main objective for students and teachers is to facilitate and accelerate the learning process so that the learning objectives and the competencies required by learners can be achieved more easily.

Bafadal (2009) explains the benefits of school library as follows: a) lead students to love reading; b) enrich students' learning experience; $c$ ) inculcate the habit of self-learning; $d$ ) speed up the process of mastering reading technique; e) help develop language skills; $f$ ) train students toward responsibility; g) facilitate students in completing school assignments; h) help teachers find teaching resources; i) help students, teachers and school staff members in following the development of science and technology.

The main benefit of school library besides acting as a learning resources is also to give a boost to the school community, especially students and teachers who use it to facilitate the learning process. The school library can also give certain motivation for students to love books more and like to read.

\section{Information and communication technology of library}

Library Automation System is the application of information technology in administrative work at the library in order to be more effective and efficient. The kinds of work that can be integrated with the system include procurement, inventory, cataloging, circulation of library materials, managing members, statistics and so forth.

The driving factors and reasons in conducting library automation are as follows:

1) Driving Factors: ease of getting IT products, the price of IT products is more affordable, the ability of information technology, digital demand of community service.

2) Other reasons: streamline and simplify the work in the library, provide better service to library users, improve library image, develop national, regional and global infrastructure.

The required library automation devices consist of two parts: hardware and software. Without the adequate presence of these two devices the automation process will not be able to run properly.

\section{a) Hardware}

Before starting the automation process, some hardware devices need to be prepared such as computer, printer, barcode, scanner, and so on. Four computers are enough to start the automation process in a small school library. While for a large library, more computers and other tools are needed to make the service run smoothly. The minimum specifications usually depend on the software used. For instance, the Senayan software (library automation program made by Diknas RI) requires a minimum of Pentium III. This is because a more graphical display requires higher specification.

\section{b) Software}

Software is absolutely needed because it is used as a tool to make the process efficient and effective. The utilization of library automation software must be in accordance with the purpose, have a license application, have relevant technical support, training, maintenance 
and documentation, and determine the staff responsible for the selection and evaluation of the software.

\section{The Competencies of School Library Administrator}

IT development in the library has considerably changed the social character of its users which includes changes in the need for information, in interacting with people, in competing, etc. Learning is not just reading a textbook course: even reading comics can be considered learning. In the end, it all leads to the users demanding that library is not just a place to read books or magazines, but a one-stop station in which users can interact with others, find the information they need, share knowledge, and feel motivated to make innovation and creativity.

Today's library and library administrators are demanded to be able to change in accordance with the social changes of its users. To anticipate the demand, library and library administrators should prepare the following (Ishak, 2008):

1) Utilizing the infrastructure of Information Technology

IT utilization is currently an obligation almost in many libraries. IT helps libraries improve the quality and type of service. At least, today's library must have local network and internet access to easily access library external information.

2) Using and organizing content Content is all documents, applications, and services that will be presented to the library users. Documents are those such as books, magazines, journals, prospectuses, financial statements, and various other forms of media, both printed and electronic. Applications are a system designed with a specific purpose, for example library administration applications, applications for storing articles downloaded from the internet, magazine administration applications, and digital library applications. Services include lending service, inter-library loan service, new book notification service via e-mail, etc.

\section{3) Pampering library users}

Library should have potential user profiles. Who are the target users? How is library perceived in their eyes? What is the position of the library to the users? What are their needs? What is the learning pattern? A kind of user survey such as psychographic segmentation can help libraries to see the learning patterns of its potential users based on adopted values and lifestyles (VALS/Value and Life Style). With in-depth knowledge about the users, the library can do promotional activities and provide appropriate services for the users.

On the other hand, the competencies of a library administrator consist of (Ishak, 2008): 1) Information Management Capability

The need for information is defined as the identification of users' need, the identification of various types of information use by the users, and the placement of information needed in a frame of reference (who, what, when, where, how, why), the connection of information needed with the knowledge domain, and the definition of information problems using a variety of question and answer skill.

Doing a search means having the basic skill of information retrieval, the ability of system navigation and using electronic resources, and basic knowledge of a variety of information resources that are not available electronically, such as printed form, people (colleagues), etc.

Knowing the sources of external and internal information, knowing which sources are reliable and have added value. 
Formulating searching strategies include the requirement of basic and comprehensive knowledge of the information resources, including the exact structure.

Other required capabilities include the ability to discuss ideas for various input; to choose a searching tool; to identify keywords, concepts, subject headers, descriptors; and to identify the criteria for evaluating the information resources.

2) Information Use

Using the information includes evaluating, assessing, integrating, selecting and interpretation of information. Evaluating means determining the authoritative, the novelty, the reliability, the relevance, and the quality. Assessing the information means to quickly see the main idea and keywords; to distinguish between fact, opinion, propaganda, point of view and bias; and to notice errors in logic. It is even better for the library administrator to have skill in doing framing analysis which will be very useful in seeing the variety of media standpoints.

Integrating information from various resources includes classifying the information, recognizing the relationship between concepts, and identifying the conflicts and similarities of various resources. Sorting of information includes the ability to sort and dispose of unnecessary information. Interpretation of information involves summarizing and identifying detailed relevant information, organizing and analyzing information, and comparing with the source of problems to be solved and drawing a conclusion.

3) Information Creation

The output of information manufacturing is a product that can help the users in making decisions. The format used can vary depending on the users' preferences. The essential skills in making information is information repackaging. In doing information repackaging, the important things that must be considered are: setting the goals of repackaging; determining the key content; selecting the right format (written, oral, visual) depending on the audience and purpose; understanding the legal implications of the repackaging process; and providing guidance, documentation, and references.

4) Information Organization

Some skills that help library administrators easily accommodate the users to find and use information are: abstracting, indexing, subject heading, and reviewing.

5) Information Dissemination

Dissemination of information requires personal skills, interpersonal skills, IT skills, and management skills. Personal skills are the ability to deliver and promote ideas clearly in a variety of forms (written, oral, presentation); to hear and evaluate opinions and information from others; and using various IT devices that have element of high interactivity, such as a portal that facilitates information sharing and a sharing knowledge forum among users. Interpersonal skills are useful for library administrators in dealing with users and fellow coworkers, and include the ability to communicate effectively and to influence others, the ability to listen and discuss others' opinion from different point of views, the ability to give good feedback to diverse situations faced by others, the ability to resolve conflicts by giving an appropriate response in a variety of situations, the ability to use formal and informal mechanisms in maintaining good relationships with fellow staff and library users, and the ability to work in a team.

IT skills are the ability to use a variety of information technology tools to assist all of the work processes. Several IT skills needed include:

- database design and management, data warehousing, and metadata

- hardware maintenance

-information architecture, electronic resources, information integration, intranet/extranet design 
-software application, programming, workflow, text processing, software for information management

- electronic publishing

Management skills involve:

-Administration: able to make a good administration system for various activities and to understand the process of library activities and other related activities.

- Management of change: able to arrange various possibilities that could arise from a change and to coordinate with other related departments.

- Leadership: has outstanding leadership character.

- Time and measuring management: able to measure performance and its effect on library services.

- Relationship management and team building: able to maintain good relations with other library administrators and library users, to build a good teamwork and can achieve the goal set.

- Training and human resource development: able to analyze the needed skills and provide the necessary training.

-Ability to conduct strategic planning and implementation.

\section{The Competencies of Information and Communication Technology}

Competency is the knowledge, skill, and basic value applied in carrying out individual task. In the information age, individuals are getting easier in obtaining information easily and quickly with the rapid technological advances. The implication of the development of information technology for libraries is that it triggers the development of digital libraries and information access via the internet, which allow individuals to obtain ease. The development of communication technology can help individuals overcome the distance and time in communicating, access or retrieve information more quickly and accurately. In order to meet the increasingly diverse need of users quickly and accurately, librarians are required to have competency in the field of information technology and are expected to deliver it with good communication.

Sulistyo-Basuki (1991) defines information technology as the technology used to store, generate, process, and disseminate information. Sulistyo-Basuki also adds that those that belong to information technology are among others: (1) telecommunication, (2) optic communication system, (3) tape-video system, (4) computers, including computer vision, data environment, and expert system, (5) microform, (6) voice communication with the aid of a computer, (7) data network, (8) electronic mail, (9) videotext and teletext.

The competency of information and communication technology is a combination of competencies in adapting computing hardware and software with the ability of communication network used for various purposes.

According to Sulistyo-Basuki (2006:8) information and communication technology competencies that should be owned by librarians include: using web browser and finding out its function; collecting data from various resources; reviewing and assessing the use of ICT in library; understanding the computer's operating system; using computer software; understanding hardware and the communication interface; data analysis; using compression data software; installing and maintaining printing machine; understanding the technique used by system analyst and designer; understanding the basic concept of system analyst; and providing technical assistance in installation and maintenance.

Meanwhile, according to Dewiyana (2006:29), the sequence of ICT competencies are:

a. Competencies in the field of technology and network management:

- Ability to use PC with a higher level than the normal everyday use

- Ability to analyze internal and external user network

- Ability to be the gate-keeper of technology in organizing sources of information 
- Ability to follow the progress and to understand information technology and its equipment

- Proficient use of in-house equipment for collecting, disseminating, and sharing information

b. Management of media storage and retrieval:

- Have the knowledge of various types of emerging storage and retrieval means.

-Always develop the knowledge and skills to anticipate the development and changes in the information industry in the future.

c. Skills in the field of information:

- Match the information needs with the information resources.

- Have expertise of the source and content of information.

- Have the expertise of information searching.

-Able to identify, evaluate, and recommend information resources.

-Provide the best medium to access information.

-Able to use the skills of organizing information into knowledge.

\section{RESEARCH QUESTIONS}

The aim of this research was to establish a competency profile standard of teacher librarians in optimizing the use of ICT in secondary level school libraries. Hence, this study is guided by the following research questions:

1. How is the profile of educational qualifications and competency of teacher librarians in secondary level?

2. How is the optimization of the use of ICT by teacher librarians in secondary level? level?

3. What is the required standard in the use of ICT for teacher librarians in secondary

\section{METHODOLOGY}

This research used qualitative approach with survey method. This method was used to determine in detail the real condition and set the standard of teacher competency profile in using ICT in the school library. The object of this study is the teacher librarians in secondary education in the province of West Java with the distribution area of Bandung City, Cianjur Regency, Tasikmalaya City, and Sumedang Regency. The number of high schools studied is three schools for each region and the number of library administrators is 12 people.

The data were collected through the following techniques:

a. Filling questionnaire was conducted to collect data from managers and librarians and other library staff to discover the facts about the competency profile of teacher librarians in the use of ICT in the school library at secondary education level.

b. Observations were carried out to corroborate the data and find facts about the competency profile of teacher librarians in the use of ICT in the secondary level school library.

The collected data were analyzed using qualitative analysis technique. The data analysis began with establishing the facts finding from the field. Then the data were presented with diagrams, tables, images, and other forms of integration of facts. As the final result, the data were interpreted, developed into propositions, principles and standards in the use of ICT for teacher librarians in secondary level school libraries.

\section{E. DISCUSSION}

This research was conducted at 12 senior high schools in four cities/regencies in West Java, namely SMAN 3, SMAN 4 and SMAN 9 in Bandung City; SMAN 1 Cianjur, SMAN 1 Cilaku and SMK 1 in Cianjur Regency, SMAN 1, SMAN 2, SMAN 5 Tasikmalaya in 
Tasikmalaya Regency; SMAN Jatinunggal in Sumedang Regency; all have library service that have been using Information and Communication Technology.

The research results showed that in general the library administrators/teacher librarians in the schools that became the sample of this study had realized that to meet the users' demand, the school library needed to be supported by the library administrators/teacher librarians who were able to use ICT to improve its service. ICT in school libraries had supported the library administrators/teacher librarians to organize library materials, perform pick up the ball service, and support the information literacy education and all the ins and outs of administrative organization of school library.

Regarding the competency profile standard of school library administrators/teacher librarians in optimizing the use of ICT in secondary level school library, the condition in the field showed the followings.

\section{The competency profile of school library administrators/teacher librarians in} secondary education in information and communication technology.

The competency profile adapted the $21^{\text {st }}$ Century Skill analyzed in this study, as shown in Table 1 below.

Tabel 1: The Competency Profile of Library Administrators/teacher Librarians

\begin{tabular}{|l|c|c|}
\hline \multicolumn{1}{|c|}{ Item } & Owned (\%) & $\begin{array}{c}\text { Not Owned } \\
(\%)\end{array}$ \\
\hline Learning and Inovation Skills & 58 & 42 \\
\hline Information, Media and Technology Skills & 62 & 38 \\
\hline Life and Career Skills & 66 & 34 \\
\hline
\end{tabular}

Generally, the measurement of competencies of the library administrators/teacher librarians or often called library staff, with the adaptation of $21^{\text {st }}$ Century Skills in the schools was at the range of adequately have all the competencies required, between $58 \%$ up to $66 \%$. This range of percentage was deemed enough to give confidence to the researchers that the library administrators/teacher librarians strived to always meet and develop the competencies that support their daily duties both in the library and in the field of study that they dealt with. The library administrators/teacher librarians we are familiar with in many schools have two strategic functions in the education process: becoming subject teachers and library staff at the same time as additional duty at school due to the lack of teaching hours required, in accordance with the government regulation which is 24 teaching hours a week.

The educational background of the teachers (at least undergraduate in their field of study) who became the library administrators was one indicator that they had the motivation to improve their competencies as library administrators/teacher librarians, especially in using ICT in organizing the libraries. From the interview, it was found that in general they improved themselves by attending training on the administration of school library whether organized by the government, non-government organization or association. It was just unfortunate that training practice related to the improvement of ICT application for library administration activities was lacking, while the theory given was very promising. As a result, the use of ICT in library became slow. Yet, Ishak (2008) revealed that library and library administrators today were demanded to be able to change in accordance with the social change of its users. To anticipate the demand, library and library administrators should prepare the followings: make use of information technology infrastructure, use and manage content, use good human resources, and pamper the users. 
In addition, it is important to note that library activities at each school are very different, dependent on the personal ability of the teacher librarians, on the school preparation of the necessary infrastructure as a real form of a library, as well as the area or the geographic location that help determine how the library develop.

\section{The Optimization of the use of ICT by library administrators/teacher librarians in secondary education.}

The description of the optimization of the use of ICT by library administrators/teacher librarians in secondary education can be analyzed in the table below.

Tabel 2: The Optimization of the Use of ICT in School Library

\begin{tabular}{|l|c|c|}
\hline \multicolumn{1}{|c|}{ Item } & $\begin{array}{c}\text { Yes/Have used } \\
\text { ICT (\%) }\end{array}$ & $\begin{array}{c}\text { No/Haven't } \\
\text { used ICT } \\
(\%)\end{array}$ \\
\hline $\begin{array}{l}\text { Utilization of hardware in library activities } \\
\text { (procurement, processing, service and } \\
\text { administration) }\end{array}$ & 89 & 11 \\
\hline $\begin{array}{l}\text { Utilization of software in library activities } \\
\text { (procurement, processing, service and } \\
\text { administration) }\end{array}$ & 62 & 38 \\
\hline
\end{tabular}

The table above indicated that, in general the use or utilization of hardware and software in library activities was satisfactory, ranging between $62 \%$ and $89 \%$. In this case the utilization of hardware tended to dominate, meaning that there were still libraries that already had adequate software but were not well adapted due to the limited expertise of human resources available.

Library administrators/teacher librarians still tended to be assisted with manual tools in conducting administration activities in library, relied a lot on printed materials in the procurement of library collection, processed library materials in printed form with very minimum variations, and provided service with manual system which had not integrated in the system. To complete the information needed by the users, library administrators/teacher librarians used hardware to find information in the internet. The findings indicated that the competencies of information and communication technology of library administrators/teacher librarians were the combination of competencies in adapting computer hardware and software with the ability of communication network used for various purposes.

However, according to Sulistyo-Basuki (1991) who defines information technology as the technology used to store, generate, process, and disseminate information, information technology involves: (1) telecommunication, (2) optic communication system, (3) tape-video system, (4) computers, including computer vision, data environment, and expert system, (5) microform, (6) voice communication with the aid of a computer, (7) data network, (8) electronic mail, (9) videotext and teletext. When the study was conducted, the library administrators/teacher librarians thought that with the ability to use computer hardware, they already had ICT competencies while the ability to increase the efficient use of ICT especially with regard to the application of software and ICT function to improve services to users could not be fully executed. Those suggested by Sulistyo-Basuki (2006) about the competencies for library administrators/teacher librarians in using ICT had not been indicated. It was hoped that the suggested competencies could be achieved, which include: using web browsers and finding out its function; collecting data from various resources; reviewing and assessing the use of ICT in library; understanding the computer's operating system; using computer software; understanding hardware and the communication interface; data analysis; using compression data software; installing and maintaining printing machine; understanding the 
technique used by system analyst and designer; understanding the basic concept of system analyst; and providing technical assistance in installation and maintenance.

\section{The competency standard required in the use of ICT for school librarians in secondary education.}

The description of the competency standard in using ICT in school library can be analyzed in Table 3 below.

Tabel 3: The Competency Standard of the Use of ICT in School Library

\begin{tabular}{|l|c|c|}
\hline \multicolumn{1}{|c|}{ Item } & Owned (\%) & Not Owned (\%) \\
\hline Attitude & 71 & 29 \\
\hline Knowledge & 87 & 13 \\
\hline Skill & 53 & 47 \\
\hline
\end{tabular}

In connection with the competency profile previously analyzed, it can be elaborated that the competency standard required and attached to teacher librarians in the use of information technology in secondary education includes basic attitude or values, knowledge and skills applied in carrying out tasks in the library. In the age of information, individuals are getting easier to obtain information quickly with the rapid development of information technology. The implications of the development of information technology for the library are among others triggering the development of digital libraries and information access via the internet, which allow individuals to obtain ease.

Based on the data obtained, generally the aspect of knowledge dominated about $87 \%$, attitude $71 \%$ and skill $53 \%$. Knowledge of the development of communication technology can help individuals overcome distance and time in communicating thus can access and obtain information more quickly and accurately. In order to meet the increasingly diverse needs of users quickly and accurately, dynamic attitude in dealing with changes and development of technology is a must because library administrators/teacher librarians should prepare for the latest information supporting the learning process. The latest information is commonly obtained through networks. Dynamic attitude and desire to move forward were already owned by the library administrators/teacher librarians. Yet, the problem of infrastructure and budget support for ICT software application training in library often hindered the creative and dynamic attitude to properly manage the library. The waiting for the presence of infrastructure and budget to develop the library resulted in the notion that library administrators/teacher librarians did not have good attitude in managing the library.

Nonetheless, the findings showed that the library administrators/teacher librarians had used web browser, collected data from various resources, used computer software, used data compression software, installed and maintained printing machine, and used ICT tools to organize information and services in the library.

\section{F. CONCLUSIONS}

All in all, the library administrators/teacher librarians in the schools that became the sample of this research always met and enhanced the competencies that supported their daily tasks in the library and in their field of study, by trying to take advantage of the hardware utilization to improve the library service to the users.

The following conclusions can be drawn:

1. The competency profile of library administrators/teacher librarians is as subject teachers who receive additional tasks to manage the library. Functionally, they are part of the educative function group, not a librarian group. They put priority in their function as subject teachers and thus put managing library as the second priority. Their educational background 
as subject teachers indicated that the majority of the library administrators/teacher librarians had willingness to study and make innovations in the library; tried to have information, media and technology literacy skills; as well as the ability to enliven the life and career related to their fields.

2. The use of ICT in school libraries is considered as the use of hardware instead of the implementation of software for library activities.

3. The competency standard of the majority of library administrators/teacher librarians in using ICT is considered good, they show good attitude, knowledge and skill but often hampered by the lack of infrastructure, budget, and practice training to apply ICT in the school library.

\section{G. RECOMMENDATIONS}

This study proposes the following recommendations.

1. Library administrators/teacher librarians should have functional status as librarians, not educative function as subject teachers.

2. Library administrators/teacher librarians need training to use software to be applied in managing the school library.

3. Library administrators/teacher librarians need to be supported by infrastructure and budget to optimize the use of ICT in school library.

4. The dynamic attitude of library administrators/teacher librarians need to be maintained by giving motivation so that the attitude can be well developed. The existing knowledge owned in the stage of understanding and comprehending need to be developed to the stage of implementing, analyzing, and synthesizing. The ICT skills need to be formally trained in order to be able to build network in meeting the users' need for information.

\section{References}

Bafadal, Ibrahim (2009). Management of School Library. Jakarta: Bumi Aksara.

Dewiyana, Himma. (2006). Competencies and Curriculum of Library: New Paradigm and Worl of Work in the Era of Information Globalization. Pustaha: Jurnal of Library and Information Study, 2(1), 22-30.

Decree of the State Minister of Administrative Reform Number 132/132/KEP/M.PAN/12/ 2002 and Joint Decision of the Head of the National Library and the Head of the Civil Service Agency No: 23 Tahun 2003 and No:21 Tahun 2003

Government Regulation No. 19 Year 2005 on National Education Standards.

Ishak. (2008). IT Based Management of Library.Pustaha: Jurnal of Library and Information Study, 4(2), 87-94.

Komaruddin, Yooke Tjuparmah S. (1989). "Library and the Information Age of Take-off Society".Bandung, Pikiran Rakyat.

Komaruddin, Yooke Tjuparmah S. (1988). "The Professionalism of School Librarians.Bandung, Pikiran Rakyat.

Komaruddin, Yooke Tjuparmah S. (1987). "The Professionalism of Librarians”. Bandung, Pikiran Rakyat. 
Komaruddin, Yooke Tjuparmah S. (1985). "University Library, the Heart of Education”. Bandung, Pikiran Rakyat.

Komaruddin, Yooke Tjuparmah S. (1989). The Obstacles of Professionalism of School Librarians. Bandung, FIP - IKIP.

Lasa, HS. (2007). Library Management. Yogyakarta: Gama Media.

Law of the Republic of Indonesia (2007). No. 43 of 2007 on the Library.

Regulation of the Minister of National Education ofthe Republic of Indonesia Number 19 of 2007 on Education Management Standards.

Regulation of the Minister of National Education ofthe Republic of Indonesia Number 25 Year 2008 on the Standard ofSchool/Madrasa Library Staff.

Rahayuningsih. (2007). Library Management. Yogyakarta: Graha IImu

Steven B. (2006). Technology Skills For Academic Librarians. ACRLog (Association of College and Research Libraries) access on June 17, 2013, from http: acrlog.org/2006/or/13/technology-skillss-for academic-librarians/

Sulistyo-Basuki. (1991). Introduction to Library Science. Jakarta: Gramedia Pustaka Utama.

Sulistyo-Basuki. (2006). The Competencies of the Graduates of Library and Information Science Study Program in the Era of Information Globalization. Pustaha: Jurnal of Library and Information Study, 2(2), 52-60.

Supriyanto, Wahyu dan Muhsin, Ahmad. (2008). Library Information Technology: Strategies in Designing Digital Library. Yogyakarta: Kanisius.

Suryana (1982). Fostering School Library: Introduction to Theory and Practice. Bandung: Paramartha.

The Act No. 20 of 2003 onthe National Education System, Ministry of National Education.

Biographical note

Yooke Tjuparmah, as senior lecturer in Library Science Program in UPI Bandung, had a comprehensive experience on running university library system as top management. Riche Cynthia Johan, as a lecturer in Library Science Program, had conduct on many research dealing with ICT and the usage in library.

Nadia Hanum, as a lecturer in Educational Technology Program doing her activity on research about resources for learning. 